\title{
Pathogenic organisms in the sputum of patients with chronic bronchitis
}

\author{
O. L. WA DE, P. C. ELMES, A N D E I LEEN BARTLEY \\ From the Department of Therapeutics and Pharmacology and the Department of Microbiology, \\ Queen's University of Belfast
}

\begin{abstract}
Bacteriological examination of the early morning sputum from 54 patients with chronic bronchitis, half of whom received chemoprophylaxis with oxytetracycline, was made regularly for periods up to four and a half years. Nasal and perineal swabs were taken for periods up to three and a half years. There was no evidence that frequent or dangerous proliferation of drug-resistant organisms occurred in the sputum of patients on prolonged chemoprophylaxis with oxytetracycline nor that a serious increase of the carriage of drug-resistant Staphylococcus pyogenes occurred in the nares or on perineal skin. In patients receiving oxytetracycline there was a significant reduction in the frequency of identification of Streptococcus pneumoniae, but the organism was not eradicated: no significant change in the frequency of identification of Haemophilus influenzae was found. From year to year there was sometimes variation in the frequency of identification of Strep. pneumoniae and Strep. pyogenes in the sputum of these patients.
\end{abstract}

The earliest manifestation of chronic bronchitis is believed to be an increase in the number and activity of the mucus-secreting cells of the bronchial mucosa, and this may predispose to infection first in exacerbations and later as a continuous process. The organisms most frequently responsible for infection are Haemophilus influenzae and Streptococcus pneumoniae, which are commonly identified in the sputum during exacerbations of chronic bronchitis (Mulder, 1938; May, 1953a, b; Edwards, Buckley, Fear, Williamson, and Zinnemann, 1957 ; Francis, May, and Spicer, 1961). These views are summarized in the report of the Scottish Health Services Council (1963).

In 1959 a controlled double-blind trial of chemoprophylaxis and chemotherapy on patients with chronic bronchitis, a history of recurrent exacerbations, and mild disability was started at 13 clinics in the United Kingdom. The trial finished in 1963 and the results have been reported (Report to Medical Research Council, 1966). This paper describes the results of a surveillance of the pathogenic organisms in the sputum and of the staphylococci carried in the nose and on the perineum of the patients in the trial at Belfast (identified as Clinic $\mathbf{K}$ in the report of the trial prepared by Fletcher and Oldham). The surveillance was initiated primarily to allow warning of the appearance of dangerous strains of drug-resistant organisms during prolonged antibiotic prophylaxis.

\section{THE PATIENTS}

Sixty-five patients were admitted to the trial in Belfast between January 1959 and April 1960. They were allocated at random to four groups (Table I):

\section{T A B L E I}

PLAN OF THE TRIAL

\begin{tabular}{ll|c|c}
\hline \multirow{2}{*}{ Prophylactic Treatment } & \multicolumn{2}{|c}{ Treatment of Exacerbation } \\
\cline { 2 - 4 } & Chloramphenicol & Sulphonamide \\
\hline Oxytetracycline $^{1}$ & $\cdots$ & $\begin{array}{c}\text { Group I } \\
\text { G patients }\end{array}$ & $\begin{array}{c}\text { Group III } \\
13 \text { patients }\end{array}$ \\
\hline Dummy tablets & $\cdots$ & $\begin{array}{c}\text { Group II } \\
14 \text { patients }\end{array}$ & $\begin{array}{c}\text { Group IV } \\
14 \text { patients }\end{array}$ \\
\hline
\end{tabular}

1 Oxytetracycline was given during winter months in the following doses: Jan. 1959-Sept. $1961,0.25 \mathrm{~g}$. twice a day: Sept. 1961-Sept. $1962,0 \cdot 5$ g. twice a day; Sept. 1962 -Sept. 1963, 1.0 g. twice a day.

GROUP I received oxytetracycline tablets throughout the winter months. This was 'prophylactic' treatment which it was hoped would prevent the exacerbations of bronchitis. If exacerbations occurred 
these patients were treated with a course of chloramphenicol.

GROUP III also received oxytetracycline throughout the winter months, but if exacerbations occurred a course of sulphadimidine was given.

GROUP II received dummy prophylactic tablets containing lactose throughout the winter months. If exacerbations occurred they were treated by a course of chloramphenicol.

GROUP IV received dummy prophylactic tablets containing lactose. If exacerbations occurred they were treated with sulphadimidine.

The allocation was not known to either patients or medical attendants until the end of the trial. Of the 65 patients admitted, 11 failed to attend regularly or moved from Belfast. Fifty-four remained under observation until the end of the trial in September 1963. They were allocated equally to the four groups (Table I). The main aim of the investigation here reported was to compare the bacterial content of the sputum of patients who received oxytetracycline throughout the winter months (groups I and III) with that of patients who did not receive oxytetracycline (groups II and IV). The skin and nasal carriage of Staphylococcus pyogenes by these patients was also examined.

METHODS OF COLLECTION AND EXAMINATION OF SPUTUM Patients attended the clinic at intervals of eight weeks during the winter months, when they were receiving the prophylactic tablets, and on two occasions, usually during June and September each summer, when they were not taking the tablets. On the day on which they attended the clinic they were asked to collect in a universal container all sputum coughed up during the first hour after rising. Forty-five patients usually attended the clinic in the morning or the afternoon, and their specimens of sputum were taken to the Department of Microbiology as soon as they attended and within three to 10 hours of production. There were nine patients who could not attend until after their,work. Their specimens of sputum, which had been in their pockets all day, were placed in a cool box (temperature $-4^{\circ} \mathrm{C}$.) overnight and taken to the Department of Microbiology the next morning, 24 hours after production. Datta (1959) reported that identification of organisms from sputum is not altered by a delay of up to 24 hours before it is examined by a bacteriologist.

Before the specimen of sputum was sent to the Department of Microbiology its volume was measured by holding the container against a ruler, and the specimen was assessed as being either mucoid, mucopurulent, or purulent (Elmes, Knox, and Fletcher, 1953).

In the Department of Microbiology each specimen of sputum, which was not homogenized, was examined by the naked eye. Standard loopfuls of the most purulent part of the specimen were spread on $\overrightarrow{\bar{\omega}}$ slides and treated with Gram's stain and a neutra! red counter stain. The presence of Strep, pneumoniae, $H$. influenzae, Strep. pyogenes, Klebsiella, and occa- $\overline{\bar{\sigma}}$ sionally other pathogenic organisms in the sputum was determined by microscopic examination of the slide. An attempt was also made to isolate the organ-n ism by standard methods of subculture. Standards loopfuls were plated out in gridiron fashion on to. $5 \%$ horse blood agar plates and on a boiled blood ${ }_{-}$ agar plate with penicillin. The plates were incubated aerobically at $37^{\circ} \mathrm{C}$. for 24 hours and then examined Unfortunately, many organisms that could be identi- $x$ fied in a specimen of sputum were not viable and could not be cultured; this was especially true ofw Strep. pneumoniae. If culture was successful thein organism was isolated and subcultured to determineor its sensitivity to penicillin, oxytetracycline, chlor-음 amphenicol, and sulphonamides.

NOSE AND SKIN SwaBS During the first four years of the trial the external nares and perineal skin were $\vec{c}$ swabbed at each attendance with swabs that weres first moistened with sterile broth. Cultures were madeby a simple plating technique on a non-selective medium and on Barber's diphenyl phosphate medium (Barber and Kuper, 1951) and the presence or absence $\overline{\bar{\sigma}}$ of Staph. pyogenes was determined. If any strain of Staph. pyogenes was isolated its sensitivity to peni-के cillin, oxytetracycline, chloramphenicol, and sulphon-은 amide was determined.

RESULTS

From the 54 patients 1,070 specimens of sputum were examined. The number of specimens considered to be mucoid and mucopurulent or puru- $x$ lent for each patient in each group was examined 3 . The data suggested that patients in groups I ando III had a greater proportion of specimens that were mucoid than did patients in the other groups, 0 but there were very great differences between? patients in the same groups, and an analysis of $\chi^{2}$ showed that the differences between groups. were not significant (Tables II and IX).

T A B LE II

PURULENCE OF SPUTUM: ANALYSIS OF $\chi^{2}$

\begin{tabular}{|c|c|c|c|c|c|}
\hline & D.F. & $x^{2}$ & $\begin{array}{c}\text { Mean } \\
\text { Square }\end{array}$ & $\mathbf{F}$ & $\underset{\text { Level }}{\text { Significance }}$ \\
\hline $\begin{array}{l}\text { Heterogeneity } \\
\text { within treatment } \\
\text { groups . . } \\
\text { Between treatments } \\
\text { Oxytetracycline v. } \\
\text { dummy . } \\
\begin{array}{l}\text { Chloramphenicol v. } \\
\text { sulphonamide }\end{array} \\
\begin{array}{l}\text { Interaction } \\
\text {. . }\end{array}\end{array}$ & $\begin{array}{r}50 \\
3 \\
1 \\
1 \\
1\end{array}$ & $\begin{array}{r}289.306 \\
15.094 \\
15.087 \\
0.0003 \\
0.0001\end{array}$ & $\begin{array}{c}5.786 \\
5.031 \\
15.087 \\
0.0003 \\
0.0001\end{array}$ & $\begin{array}{l}-\overline{<1} \\
2 \cdot 61 \\
<1 \\
<1\end{array}$ & $\begin{array}{c}\mathbf{P}<0.001 \\
\mathbf{P}>0.2 \\
0.2>\mathbf{P}>0.1 \\
\mathbf{P}>0.2 \\
\mathbf{P}>0.2\end{array}$ \\
\hline
\end{tabular}


Strep. pneumoniae IN THE SPUTUM This organism was identified on 282 occasions. It was identified less frequently from specimens of sputum of patients in groups I and III than from those of patients in groups II and IV during the winter months, when 'prophylactic' tablets were being taken (Table III).

\section{T A B L E I I I}

STREP. PNEUMONIAE IDENTIFIED FROM 1,070 SPECIMENS OF SPUTUM

\begin{tabular}{|c|c|c|c|c|}
\hline \multirow[b]{2}{*}{ Group } & \multicolumn{2}{|c|}{ Non-prophylactic Time } & \multicolumn{2}{|c|}{ Prophylactic Time } \\
\hline & $\begin{array}{c}\text { No. of } \\
\text { Specimens }\end{array}$ & $\begin{array}{c}\text { Specimens } \\
\text { from which } \\
\text { Strep. } \\
\text { pneumoniae } \\
\text { Identified }\end{array}$ & $\begin{array}{c}\text { No. of } \\
\text { Specimens }\end{array}$ & $\begin{array}{l}\text { Specimens } \\
\text { from which } \\
\text { Strep. } \\
\text { pneumoniae } \\
\text { Identified }\end{array}$ \\
\hline $\begin{array}{l}\text { I } \\
\text { II } \\
\text { III } \\
\text { IV }\end{array}$ & $\begin{array}{l}94 \\
91 \\
98 \\
91\end{array}$ & $\begin{array}{l}23 \\
28 \\
37 \\
33\end{array}$ & $\begin{array}{l}165 \\
190 \\
163 \\
178\end{array}$ & $\begin{array}{l}27 \\
64 \\
23 \\
47\end{array}$ \\
\hline $\begin{array}{l}\text { I and III } \\
\text { II and IV }\end{array}$ & $\begin{array}{l}192 \\
182\end{array}$ & $\begin{array}{l}60 \\
61\end{array}$ & $\begin{array}{l}328 \\
368\end{array}$ & $\begin{array}{r}50 \\
111\end{array}$ \\
\hline
\end{tabular}

The number of specimens from which Strep. pneumoniae were identified and were not identified from each individual patient was examined and a $\chi^{2}$ analysis shows that the difference between patients who received prophylactic oxytetracycline and those who did not is highly significant (Table IV).

The frequency of identification of Strep. pneumoniae varied from year to year (Table V). There was a marked reduction in frequency in 1961-2 and 1962-3. These were the years in which increased doses of prophylactic oxytetracycline were given to patients in groups I and III. There was, however, a reduction in the frequency of identification of Strep. pneumoniae in sputum
T A B LE I V

STREP. PNEUMONIAE IN SPUTUM: ANAIYSIS OF $\chi^{2}$

\begin{tabular}{|c|c|c|c|}
\hline & D.F. & $x^{2}$ & Significance Level \\
\hline $\begin{array}{l}\text { Heterogeneity within treat- } \\
\text { ment groups } \quad . . \\
\text { Between treatments.. } \\
\text { Oxytetracycline v. dummy... } \\
\text { Chloramphenicol v. sulphon- }\end{array}$ & $\begin{array}{r}50 \\
3 \\
1\end{array}$ & $\begin{array}{l}56 \cdot 374 \\
15 \cdot 634 \\
14 \cdot 239\end{array}$ & $\begin{array}{c}0.3>\mathbf{P}>0.2 \\
0.01>\mathbf{P}>0.001 \\
P<0.001\end{array}$ \\
\hline $\begin{array}{cccc}\text { amide } & \cdots & \cdots & \cdots\end{array}$ & $\begin{array}{l}1 \\
1\end{array}$ & $\begin{array}{l}0.002 \\
1.204\end{array}$ & $\begin{aligned} P & >0.95 \\
0.3 & >P>0.2\end{aligned}$ \\
\hline
\end{tabular}

specimens from patients in groups II and IV who were not receiving oxytetracycline.

Strains of Strep. pneumoniae were successfully isolated 59 times. Twenty of these strains were resistant to penicillin. Five strains were isolated resistant to tetracycline, two from patients who were not receiving oxytetracycline prophylaxis. No strains resistant to chloramphenicol were isolated. Nine strains resistant to sulphonamides were isolated; they were found in the sputum of patients in all four groups.

$H$. influenzae IN THE SPUTUM This organism was identified 213 times (Table VI). It was identified

\section{T A B L E V I}

H. INFLUENZAE IDENTIFIED FROM 1,070 SPECIMENS OF SPUTUM

\begin{tabular}{c|c|c|c|c}
\hline & \multicolumn{2}{|c|}{ Non-prophylactic Time } & \multicolumn{2}{|c}{ Prophylactic Time } \\
\cline { 2 - 4 } Group & $\begin{array}{c}\text { No. of } \\
\text { Specimens }\end{array}$ & $\begin{array}{c}\text { Specimens } \\
\text { from which } \\
\text { H. influenzae } \\
\text { Identified }\end{array}$ & $\begin{array}{c}\text { No. of } \\
\text { Specimens }\end{array}$ & $\begin{array}{c}\text { Specimens } \\
\text { from which } \\
H \text {. infuenzae } \\
\text { Identified }\end{array}$ \\
\hline II & 94 & 17 & 165 & 36 \\
III & 91 & 17 & 190 & 51 \\
IV & 98 & 13 & 163 & 24 \\
\hline I and III & 192 & 15 & 178 & 40 \\
II and IV & 182 & 30 & 328 & 60 \\
\hline
\end{tabular}

T A B L E V

STREP. PNEUMONIAE IDENTIFIED FROM SPUTUM, BY TIME

\begin{tabular}{|c|c|c|c|c|c|c|c|c|}
\hline \multirow{3}{*}{ Time } & \multicolumn{4}{|c|}{ Groups I and III } & \multicolumn{4}{|c|}{ Groups II and IV } \\
\hline & \multicolumn{2}{|c|}{ Non-prophylactic Time } & \multicolumn{2}{|c|}{ Prophylactic Time } & \multicolumn{2}{|c|}{ Non-prophylactic Time } & \multicolumn{2}{|c|}{ Prophylactic Time } \\
\hline & $\begin{array}{c}\text { No. of } \\
\text { Specimens }\end{array}$ & $\begin{array}{c}\text { Strep. } \\
\text { pneumoniae } \\
\text { Identified } \\
(\%)\end{array}$ & $\begin{array}{c}\text { No: of } \\
\text { Specimens }\end{array}$ & $\begin{array}{c}\text { Strep. } \\
\text { pneumoniae } \\
\text { Identified } \\
(\%)\end{array}$ & $\begin{array}{c}\text { No. of } \\
\text { Specimens }\end{array}$ & $\begin{array}{c}\text { Strep. } \\
\text { pneumoniae } \\
\text { Identified } \\
(\%)\end{array}$ & $\begin{array}{c}\text { No. of } \\
\text { Specimens }\end{array}$ & $\begin{array}{c}\text { Strep. } \\
\text { pneumoniae } \\
\text { Identified } \\
(\%)\end{array}$ \\
\hline $\begin{array}{c}1959 \text {, Jan.-Sept. } \\
1959-60 \\
1960-61 \\
1961-62 \\
1962-63\end{array}$ & $\begin{array}{l}30 \\
41 \\
27 \\
51 \\
43\end{array}$ & $\begin{array}{l}37 \\
41 \\
48 \\
18 \\
23\end{array}$ & $\begin{array}{l}15 \\
70 \\
95 \\
73 \\
75\end{array}$ & $\begin{array}{r}27 \\
27 \\
16 \\
8 \\
8\end{array}$ & $\begin{array}{l}26 \\
27 \\
28 \\
50 \\
51\end{array}$ & $\begin{array}{l}34 \\
37 \\
60 \\
21 \\
28\end{array}$ & $\begin{array}{r}11 \\
90 \\
106 \\
78 \\
83\end{array}$ & $\begin{array}{l}37 \\
41 \\
32 \\
21 \\
24\end{array}$ \\
\hline Total & 192 & 31 & 328 & 15 & 182 & 33 & 368 & 30 \\
\hline
\end{tabular}


less frequently from the specimens of sputum of patients in groups I and III when they were taking oxytetracycline than from specimens of the patients in groups II and IV. There was great variation from patient to patient within each group and an analysis of $\chi^{2}$ showed this difference was not significant (Table VII). The frequency of identification of $H$. influenzae varied little from year to year or season to season over the period of the study.

T A B LE V I I

H. INFLUENZAE IN SPUTUM: ANALYSIS OF $\chi^{2}$

\begin{tabular}{|c|c|c|c|c|c|}
\hline & D.F. & $\chi^{2}$ & $\begin{array}{l}\text { Mean } \\
\text { Square }\end{array}$ & $\mathbf{F}$ & $\begin{array}{c}\text { Significance } \\
\text { Level }\end{array}$ \\
\hline $\begin{array}{c}\begin{array}{l}\text { Heterogeneity within } \\
\text { treatment groups }\end{array} \\
\text { Between treatments } \\
\text { Oxytetracycline v. } \\
\text { dummy } \\
\begin{array}{c}\text { Chloramphenicol v. } \\
\text { sulphonamide }\end{array} \\
\begin{array}{c}\text { Interaction } \quad . \\
\text {. }\end{array}\end{array}$ & $\begin{array}{r}50 \\
3 \\
1 \\
1 \\
1\end{array}$ & $\begin{array}{r}87 \cdot 704 \\
8 \cdot 737 \\
4 \cdot 358 \\
4 \cdot 382 \\
0 \cdot 319\end{array}$ & $\begin{array}{l}1 \cdot 754 \\
2 \cdot 912 \\
4 \cdot 358 \\
4 \cdot 382 \\
0 \cdot 319\end{array}$ & $\begin{array}{l}\overline{1 \cdot 66} \\
2 \cdot 48 \\
2 \cdot 50 \\
<1\end{array}$ & $\begin{array}{c}\mathbf{P}<0.001 \\
0.2>\mathbf{P}>0.1 \\
0.2>\mathbf{P}>0.1 \\
0.2>\mathbf{P}>0.1 \\
\mathbf{P}>0.2\end{array}$ \\
\hline
\end{tabular}

Strains of $H$. influenzae were isolated 159 times, on 61 occasions from specimens of patients in groups I and III and on 98 occasions from specimens of patients in groups II and IV. One-fifth of the strains isolated from patients in groups I and III were resistant to oxytetracycline and $14 \%$ of the strains from patients in groups II and IV. There were 48 strains isolated which were resistant to sulphonamides, but only 20 of these were from patients in groups III and IV who were given sulphonamides if they had exacerbations of their bronchitis. Strains resistant to chloramphenicol were isolated on eight occasions.

Strep. pyogenes IN THE SPUTUM This organism and 29 of these were in the last year of the study, 1962-3. It was the only pathogen identified more frequently in summer months than in winter months. was identified on only 45 occasions (Table VIII)

T A B LE VIII

STREP. PYOGENES IDENTIFIED FROM 1,070 SPECIMENS OF SPUTUM

\begin{tabular}{|c|c|c|c|c|}
\hline \multirow[b]{2}{*}{ Group } & \multicolumn{2}{|c|}{ Non-prophylactic Time } & \multicolumn{2}{|c|}{ Prophylactic Time } \\
\hline & $\begin{array}{c}\text { No. of } \\
\text { Specimens }\end{array}$ & $\begin{array}{c}\text { Specimens } \\
\text { from which } \\
\text { Strep. } \\
\text { pyogenes } \\
\text { Identified }\end{array}$ & $\begin{array}{c}\text { No. of } \\
\text { Specimens }\end{array}$ & \begin{tabular}{|c} 
Specimens \\
from which \\
Strep. \\
pyogenes \\
Identified
\end{tabular} \\
\hline$\underset{\text { III }}{\text { II }}$ & $\begin{array}{l}94 \\
91 \\
98 \\
91\end{array}$ & $\begin{array}{l}8 \\
5 \\
6 \\
4\end{array}$ & $\begin{array}{l}165 \\
190 \\
163 \\
178\end{array}$ & $\begin{array}{l}3 \\
7 \\
6 \\
6\end{array}$ \\
\hline
\end{tabular}

OTHER PATHOGENIC ORGANISMS Other organisms ô identified occasionally included Staph. pyogenes, Klebsiella, and Escherichia coli. There was a tendency for these organisms to be identified $\vec{z}$ more frequently from the sputum of patients who received prophylactic oxytetracycline than from those who did not. There were two patients from $\odot$ whom Klebsiella was recurrently cultured over. a period of two years.

The frequency of identification of pathogens was remarkably similar whether the sputum was mucoid, mucopurulent, or purulent (Table IX).

BACTERIAL CONTENT OF SPUTUM SMEARS This $\overrightarrow{\bar{O}}$ assessment was of little value. In $70 \%$ of smears it was assessed as average, in $20 \%$ as slight, and in $10 \%$ as heavy. These assessments were not related:to the frequency of identification of pathogenic organisms nor to whether the sputum was mucoid, mucopurulent, or purulent.

NASAL AND SKIN CARRIAGE OF STAPHYLOCOCCI From the beginning of the trial until May 1962, 778 nasal swabs were taken and cultured (Tableo $\mathrm{X})$. Staph. pyogenes was isolated 103 times. Almost half the strains were resistant to penicillin. Strainso resistant to chloramphenicol were found on $21_{N}$ occasions and sulphonamide-resistant strains on

T A B L E IX

PATHOGENS AND PURULENCE OF SPUTUM

\begin{tabular}{|c|c|c|c|c|c|c|c|c|}
\hline & \multicolumn{4}{|c|}{ Groups I and III } & \multicolumn{4}{|c|}{ Groups II and IV } \\
\hline & \multicolumn{2}{|c|}{ Non-prophylactic Time } & \multicolumn{2}{|c|}{ Prophylactic Time } & \multicolumn{2}{|c|}{ Non-prophylactic Time } & \multicolumn{2}{|c|}{ Prophylactic Time } \\
\hline & Mucoid & $\begin{array}{l}\text { Muco- } \\
\text { purulent } \\
\text { or } \\
\text { Purulent }\end{array}$ & Mucoid & $\begin{array}{c}\text { Muco- } \\
\text { purulent } \\
\text { or } \\
\text { Purulent }\end{array}$ & Mucoid & $\begin{array}{l}\text { Muco- } \\
\text { purulent } \\
\text { or } \\
\text { Purulent }\end{array}$ & Mucoid & $\begin{array}{c}\text { Muco- } \\
\text { purulent } \\
\text { or } \\
\text { Purulent }\end{array}$ \\
\hline $\begin{array}{l}\text { No. of specimens } \\
\text { Strep. pneumoniae identified }(\%) \\
H \text {. infuenzae identified }(\%)\end{array}$ & $\begin{array}{r}129 \\
31 \\
12\end{array}$ & $\begin{array}{l}63 \\
32 \\
20\end{array}$ & $\begin{array}{r}240 \\
15 \\
19\end{array}$ & $\begin{array}{l}88 \\
17 \\
18\end{array}$ & $\begin{array}{r}113 \\
36 \\
15\end{array}$ & $\begin{array}{l}69 \\
29 \\
22\end{array}$ & $\begin{array}{r}215 \\
31 \\
24\end{array}$ & $\begin{array}{r}153 \\
29 \\
25\end{array}$ \\
\hline
\end{tabular}


T A B L E $X$

NASAL CARRIAGE OF STAPH. PYOGENES

\begin{tabular}{|c|c|c|c|c|c|}
\hline & $\underset{1}{\text { Group }}$ & $\underset{2}{\text { Group }}$ & $\underset{3}{\text { Group }}$ & $\underset{4}{\text { Group }}$ & Total \\
\hline $\begin{array}{l}\text { No. of patients } . . \\
\text { No. of swabs } \\
\text { Staphylococci isolated } . . \\
\text { Penicillin-resistant } \\
\text { Tetracycline-resistant } \\
\text { No. of patients from } \\
\text { whom staphylococci } \\
\text { isolated five or more } \\
\text { times . . } . . . \\
\text { No. of patients from } \\
\text { whom staphylococci } \\
\text { never isolated }\end{array}$ & $\begin{array}{r}13 \\
191 \\
23 \\
9 \\
15\end{array}$ & $\begin{array}{r}14 \\
207 \\
21 \\
12 \\
10\end{array}$ & $\begin{array}{r}13 \\
189 \\
17 \\
8 \\
10\end{array}$ & $\begin{array}{r}14 \\
191 \\
42 \\
20 \\
6\end{array}$ & $\begin{array}{r}54 \\
778 \\
103 \\
49 \\
41\end{array}$ \\
\hline
\end{tabular}

44 occasions. Oxytetracycline-resistant strains were found on 41 occasions.

Although patients in groups I and III who were receiving prophylactic oxytetracycline were found to be carrying Staph. pyogenes less frequently than patients in the other groups, they carried oxytetracycline-resistant strains slightly more frequently. There was no evidence that the carriage of Staph. pyogenes was related to season or year.

During the same period 778 perineal skin swabs were taken and cultured (Table XI). Staph. pyogenes was isolated only 13 times. There was

T A B LE XI

SKIN CARRIAGE OF STAPH. PYOGENES

\begin{tabular}{|c|c|c|c|c|c|}
\hline & $\underset{1}{\text { Group }}$ & $\underset{2}{\text { Group }}$ & $\underset{3}{\text { Group }}$ & $\underset{4}{\text { Group }}$ & Total \\
\hline $\begin{array}{l}\text { No. of swabs } \\
\text { Staphylococci isolated } \\
\quad \text { Penicillin-resistant } \\
\text { Tetracycline-resistant }\end{array}$ & $\begin{array}{r}191 \\
5 \\
4 \\
4\end{array}$ & $\begin{array}{r}207 \\
2 \\
1 \\
1\end{array}$ & $\begin{array}{r}189 \\
5 \\
3 \\
4\end{array}$ & $\begin{array}{r}191 \\
1 \\
1 \\
0\end{array}$ & $\begin{array}{r}778 \\
13 \\
9 \\
9\end{array}$ \\
\hline
\end{tabular}

a tendency for patients who received oxytetracycline to carry penicillin-resistant and oxytetracycline-resistant organisms more than the patients who did not receive prophylactic oxytetracycline.

\section{DISCUSSION}

The main purpose of the bacteriological surveillance of the sputum and of the strains of Staph. pyogenes carried in the nose and on the skin was achieved. There was no evidence that dangerous proliferation of drug-resistant organisms occurred during prolonged prophylaxis with antibiotics.

In retrospect it is believed that bacteriological surveillance would have been more informative if morning specimens of sputum could have been obtained within an hour of their production, and if they could have been obtained far more frequently from each patient. It is probable that culture and isolation of organisms would then have been much more frequent. But even the simple investigations which are here described demanded much co-operation from the patients and were arduous for the investigators, continuing as they did for four and a half years.

The only significant effect of the prophylactic oxytetracycline detected was a small reduction in the frequency with which Strep. pneumoniae was identified. There is no evidence that this paucity of effect of oxytetracycline was due to insufficient dosage (doses of $2 \mathrm{~g}$. per day were given in the last year), to failure of patients to take their tablets (Report to M.R.C., 1966), or to frequent development of strains of Strep. pneumoniae resistant to oxytetracycline. The fact that most strains of Strep. pneumoniae isolated were sensitive to oxytetracycline suggests that the drug did not reach the sputum in adequate concentrations. May and Delves (1965) have recently shown that when sputum is mucoid, ampicillin is not present in bactericidal concentrations even though present in high concentration in the blood. In our investigation the frequency of identification of pathogens was similar whether the sputum was mucoid, mucopurulent, or purulent, and there was no evidence that the effect of oxytetracycline on the flora was modified by the type of sputum.

There were great variations in the frequency of identification of Strep. pneumoniae and Strep. pyogenes in the sputum from year to year but little variation in the frequency of identification of $H$. influenzae. Previous investigations in this department have suggested that there might be a seasonal variation in the carriage of Strep. pneumoniae in the sputum of patients in the community. This, as well as differences in bacteriological techniques, may account for the differing results reported by workers who have investigated the bacterial flora of the sputum of patients with chronic bronchitis (Scottish Health Services Council, 1963).

The results of the full controlled trial have been reported (Report to M.R.C., 1966). These showed that prophylaxis with oxytetracycline during the winter months had no consistent effect on the number of exacerbations of chronic bronchitis that patients suffered. In combination with chloramphenicol, prophylactic oxytetracycline reduced the number of illnesses significantly in patients with frequent illness, but in combination 
with sulphonamides it had no effect. Prophylaxis with oxytetracycline was associated with a reduction in the average length of illness as estimated by the time lost from work. But the estimate of the average decrease in length $(16 \%)$ that could be made from the data was uncertain. In the discussion of the findings it was questioned whether bacterial superinfection plays as important a part in exacerbations of chronic bronchitis as is generally believed. The findings of our investigation suggest that prophylactic oxytetracycline makes remarkably little difference to the presence of pathogenic organisms that can be cultured from the sputum of these patients.

We wish to thank our patients, who co-operated loyally and patiently in these long-continued studies.

We are deeply indebted to Dr. J. Smiley, who gave us facilities which made this survey possible, and to Drs. C. M. Fletcher and P. D. Oldham, who sent us an early draft of their report on the controlled therapeutic trial and gave helpful advice and criticism. We acknowledge gratefully the help we have received from Dr. E. E. Turkington, Department of Medical Statistics, Queen's University, Belfast, and Dr. P. D. Oldham, Pneumoconiosis Research Unit, Cardiff. The
Wellcome Foundation, the Medical Research Council, $\overrightarrow{\vec{s}}$ and the Medical Education and Research Committteeof the Northern Ireland Hospitals Authority gave financial support towards this work.

\section{REFERENCES}

Barber, M., and Kuper, S. W. A. (1951). Identification of Staphylo- $\vec{\circ}$ coccus pyogenes by the phosphatase reactions. J. Path. Bact., 63,65 .

Datta, N. (1959). Personal communication.

Edwards, G., Buckley, A. R., Fear, E. C., Williamson, G. M., and Zinnemann, K. (1957). Adult chronic bronchitis, the infective factor and its treatment. Brit. med. J., 2, 259.

Elmes, P. C., Knox, K., and Fletcher, C. M. (1953). Sputum in N chronic bronchitis: effects of antibiotics. Lancet, $2,903$.

Francis, R. S., May, J. R., and Spicer, C. C. (1961). Chemotherapy of bronchitis: influence of penicillin and tetracycline administered $O$ daily, or intermittently for exacerbations. Brit. med.J., 2, 979 . \&

May, J. R. (1953a). The bacteriology of chronic bronchitis. Lancet, 2,534 .

- (1953b). Antibiotics in chronic bronchitis. Ibid., 2, 899. and Delves, D. M. (1965). Treatment of chronic bronchitis with ampicillin. Ibid., 1, 929.

Mul der, J. (1938). Haemophilus influenzae (Pfeiffer) as an ubiquitous cause of common acute and chronical purulent bronchitis. Acta $\overrightarrow{0}$ med. scand., 94, 98.

Report to Me dical Research Council (1966). (Prepared by C. M.. Fletcher and P. D. Oldham). The value of chemoprophylaxis and chemotherapy in early chronic bronchitis. Brit. med. J., $1,1317$. Scottish Health Services Council (1963). Bronchitis. H.M.S.O.,
Edinburgh. 